\title{
Performance of lime calcined clay cement-an experimental and microstructural evaluation
}

\author{
Sumedha Moharana ${ }^{1} \cdot$ Priya Gupta ${ }^{1}$ \\ Received: 14 October 2021 / Accepted: 17 December 2021 / Published online: 18 January 2022 \\ (c) The Author(s), under exclusive licence to Springer Nature Switzerland AG 2022
}

\begin{abstract}
Portland cement is widely used in the construction industry because of its reasonable strength bearing capacity under the load and hydraulic behaviour, but it emits $5 \%$ of global carbon dioxide. Calcium sulfoaluminate (CSA) cement is the alternative binder, which provides the same strength as Portland cement and reduces the emission of carbon dioxide. This paper presents the experimental investigation and microstructural study of two different mixes of CSA cement. Lab-based physical tests were conducted for CSA and ordinary Portland cement (OPC) cement for basic hydraulic characteristics (setting, fineness, specific gravity, etc.). The microstructural studies were done for 1, 7, and 28 days for OPC and CSA cement. The phase volume diagram for CSA cement has been formulated using hydration kinetics. Through microstructural analysis, it is found that the clinker formed from the proposed blend of binders has extremely satisfactory in terms of physical setting property and hydration compound formation.
\end{abstract}

Keywords Calcium sulfo-aluminate cement $\cdot$ Hydration $\cdot$ Ye'elimite $\cdot$ Ettringite $\cdot \mathrm{CO}_{2} \cdot$ Lime calcined clay

\section{Introduction}

Because of its strong bearing and hydraulic qualities, Portland cement is commonly acknowledged as the primary construction material. Many famous infrastructures, to mention a few, have relied on it for strength and endurance in recent decades. However, manufacturing of ordinary portland cement (OPC) contributes around 5\% to the global carbon dioxide. The manufacturing of 1 ton of cement produces around $800 \mathrm{kgs}$ of $\mathrm{CO}_{2}[1]$. This high release of $\mathrm{CO}_{2}$ is shifting the attention of researchers to other alternative construction materials. Many researchers attempt to find solutions to make the construction materials environmentally friendly and hunt for completely new binders for net zero energy approach. [2-5]. In the last decades, lime calcined clay has gained more popularity in western Europe and China for its excellent setting property and durability. Calcium sulfoaluminate cement (CSA) is one of its kind alternative

Sumedha Moharana

sumedha.maharana@snu.edu.in

Priya Gupta

priyagupta0897@gmail.com

1 Department of Civil Engineering, Shiv Nadar University, Greater Noida, India binders. It is not fully investigated due to limited studies and commercial applicability, and people in India are not commercially aware of its benefits. To date, China is the largest CSA cement manufacturer and user in worldwide. Calcium sulfoaluminate cement is clinkered as like OPC, at temperature around $1100^{\circ} \mathrm{C}-1200^{\circ} \mathrm{C}$, which is $200^{\circ} \mathrm{C}$ less than the temperature required for OPC $1450^{\circ}-1500^{\circ} \mathrm{C}$. Hence, less fuel will be required in the kiln, further reducing the carbon dioxide emission $[6,7]$. The CSA clinker is a very soft texture and can be ground into fine particles with less energy, which again implies the green alternative. Hence, in overall, the production of CSA cement results in the reduction of $\mathrm{CO}_{2}$ by $18 \%$. [8]. CSA cement is not only a better alternative over Portland cement, but it has a major advantage for rapid hardening and setting properties [9-12]. Also, It has significant resistance against freezing and thawing effects. $[13,14]$ The amount of gypsum added plays a very important role in achieving desired setting time and hardening for CSA cement, and similar best results are reported for 15 to $25 \%$ addition to raw mixture[ 15,16$]$. The percentage composition of calcium sulfate in CSA constituents, controls the exothermic hydration mechanism and formation of hydrated products (mainly Ettringite) in the initial hardening process. It also contributes for production of minor phases 
(Ye'elimite, alite, belite, ferrite, strangilite, and portlandite) in CSA cement clinkering $[17,18]$.

The paper deals with the physical and microstructural study of CSA cement. The main component of this study is clinkering of CSA cement using locally available waste products which are discarded by the marble industries (Marble slurry and powder) and cheap Kaolite for fining costeffective and environmental friendly binder. Two different CSA cement has been proposed with varying mix proportions of raw materials. The basic physical properties were evaluated for both OPC and CSA cement in accordance to established standards. Microstructural properties were studied to understand the hydration kinetics and phase formation during hydration for CSA cements for 1, 7, and 28 days through morphological, phase diffraction and thermo

Table 1 Mix proportion of raw materials for CSA clinkers

\begin{tabular}{lcc}
\hline Raw ingredient & Mix 1 & Mix 2 \\
\hline Lime Stone Powder & $33.35 \%$ & $40.00 \%$ \\
Gypsum & $22.00 \%$ & $20.00 \%$ \\
Kaolite Powder & - & $25.00 \%$ \\
Marble Slurry & $25.51 \%$ & - \\
Aluminum Powder & $19.14 \%$ & $15.00 \%$ \\
\hline
\end{tabular}

gravimetric analysis. The ternary diagrams were plotted for OPC and CSA mixes to predicting the phase assemblage of hydrated cements.

\section{Materials and methods}

The ordinary Portland cement was procured through commercial supplier, whereas the CSA cement of two different mixes was prepared in the laboratory. The two CSA mixes were prepared with different proportions of raw ingredient and named as CSA-I and CSA-2. The mixed proportions are listed in Table 1 . The raw ingredients were chosen for the CSA cement almost the same OPC, but varies for aluminate to sulfate ion concentration. This is achieved by adding marble slurry and kaolinite with different proportions. Reference standards to include these materials are already in place [19-21]. Powders were blended together using a tubular blender for $20 \mathrm{~min}$. The mixtures of appropriate proportions (refer Table 1) were put in a muffle furnace at $950{ }^{\circ} \mathrm{C}$ for $4 \mathrm{~h}$ (Patent from FLSmidth) for calcination (see Fig. 1). A heating rate of $10{ }^{\circ} \mathrm{C} \mathrm{min}^{-1}$ is used to get an experiment time of approximately $2 \mathrm{~h}$, including cooling down [22]. After calcination, the materials were ground in a vibratory disk mill with a speed of $700 \mathrm{~min}^{-1}$ for $10 \mathrm{~min}$ and using

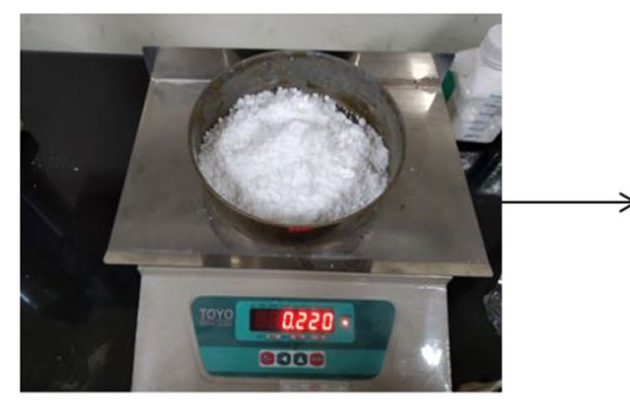

Weighing of sample Materials

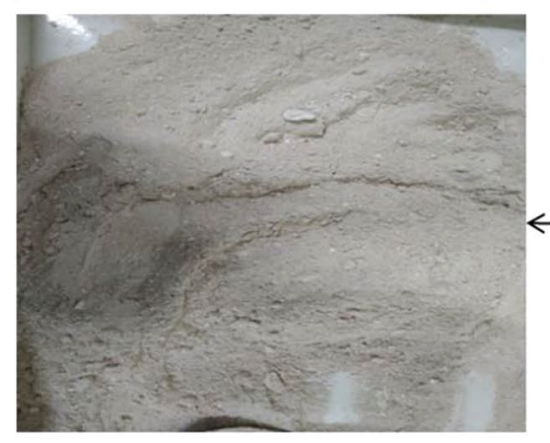

Grinded Cement Clinker

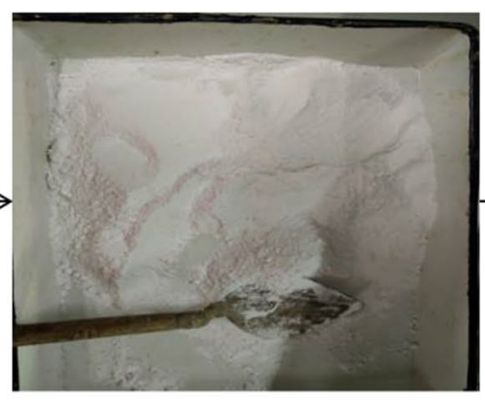

Mixing of sample

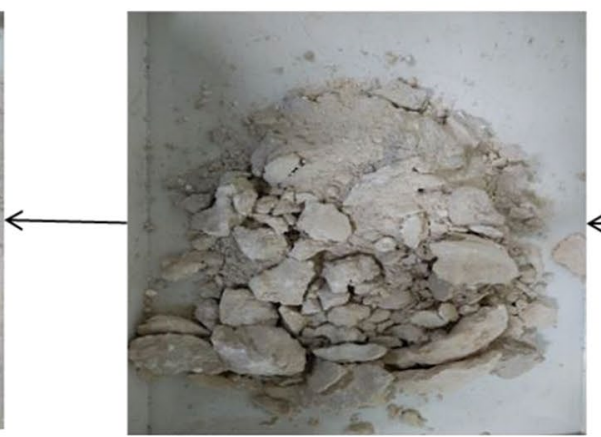

Cement Clinker

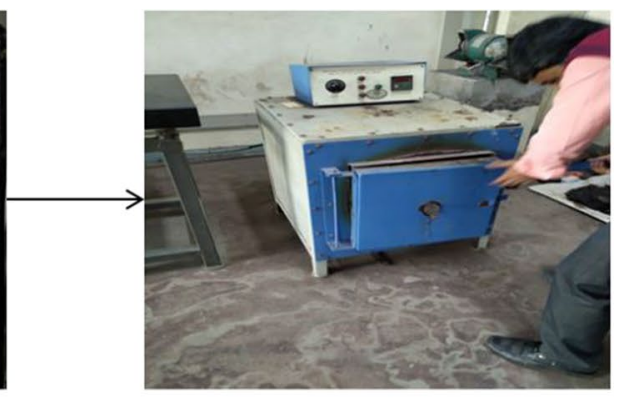

Clinkering of sample (a) $1250{ }^{\circ} \mathrm{C}$

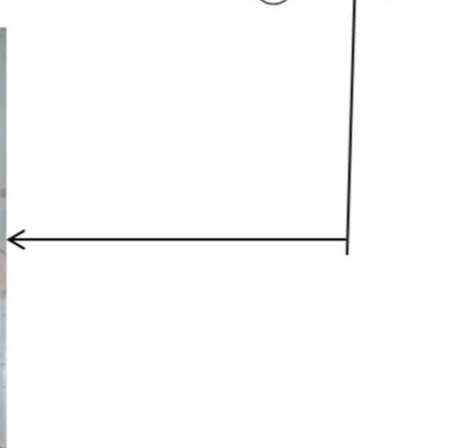

Fig. 1 Clinkering of CSA cement 
Table 2 Chemical analysis of CSA mixes

\begin{tabular}{lll}
\hline Composition & CSA 1 & CSA 2 \\
\hline $\mathrm{CaO}(w t \%)$ & 10.4 & 32.58 \\
$\mathrm{SiO}_{2}(\mathrm{wt} \%)$ & 6.5 & 14.34 \\
$\mathrm{Al}_{2} \mathrm{O}_{3}(\mathrm{wt} \%)$ & 63 & 28 \\
$\mathrm{Fe}_{2} \mathrm{O} 3(\mathrm{wt} \%)$ & 0.8 & 0.35 \\
$\mathrm{MgO}(\mathrm{wt} \%)$ & 1.74 & 0.13 \\
$\mathrm{SO}_{3}(\mathrm{wt} \%)$ & 15 & 17 \\
$\mathrm{Na}_{2} \mathrm{O}(\mathrm{wt} \%)$ & 0.78 & 0.78 \\
$\mathrm{~K}_{2} \mathrm{O}(\mathrm{wt} \%)$ & 0.46 & 0.48 \\
$\mathrm{LOI}(\mathrm{wt} \%)$ & 1.5 & 5.8 \\
\hline
\end{tabular}

LOI Loss of Ignition

Table 3 Physical characterization of cementitious materials

\begin{tabular}{llll}
\hline Physical Properties & OPC & CSA 1 & CSA 2 \\
\hline Specific Gravity & 2.80 & 2.5 & 2.72 \\
Specific Surface Area & $261.14 \mathrm{~m}^{3} / \mathrm{kg}$ & $260 \mathrm{~m}^{3} / \mathrm{kg}$ & $300 \mathrm{~m}^{3} / \mathrm{kg}$ \\
Consistency & $29 \%$ & $46 \%$ & $50 \%$ \\
Initial Setting Time & $50 \mathrm{~min}$ & $30 \mathrm{~min}$ & $15 \mathrm{~min}$ \\
Final Setting Time & $600 \mathrm{~min}$ & $390 \mathrm{~min}$ & $120 \mathrm{~min}$ \\
Compressive Strength & $8.49 \mathrm{~N} / \mathrm{mm}^{2}$ & $2.06 \mathrm{~N} / \mathrm{mm}^{2}$ & $6.10 \mathrm{~N} / \mathrm{mm}^{2}$ \\
\hline
\end{tabular}

an agate grinding tool and screened through a sieve mesh of $100 \mu \mathrm{m}$ [23-25] (see Fig. 1).

All the lab-based basic physical tests of cements were conducted, i.e. specific gravity, specific surface area, consistency, initial setting time and final setting time, compressive strength test. The test procedures have complied with Indian standards [26-28] and international standards [29, 30]. For compressive strength, the mortar cubes were cast on mould $(70.7 \mathrm{mmX} 70.6 \mathrm{mmX} 70.6 \mathrm{~mm})$ for both OPC and CSA mixes [30, 31]. Once demolded, the sample is air-cured for 3 and 7 days respectively and then tested for the compressive strength test. The chemical composition of CSA mixes has done through mass spectroscopy. The results are tabulated in Table 2

\subsection{Physical test results in cement samples}

The physical properties of CSA mixes are tabulated in Table 3. From Table 3, it is noticed that the specific gravity of OPC is higher than the calcium sulfoaluminate cement due to the porous nature of CSA clinker [32-34]. The consistency of CSA cement is marginally high than the OPC cement, needs more water content to achieve the same workability as OPC. This higher water requirement attributes the change in CSH composition (enrichment in Aluminium, longer CSH chains), provides resistance to sulphur attack [4, 35, 36]. The setting time required for CSA cement is lesser than the OPC, which implies rapid hardening [37]. The

Initial setting time for CSA cement is around 15-30 min, whereas the final setting time is between 120 to $390 \mathrm{~min}$. In terms of mechanical strength, the compressive strength of CSA cement is found to be very low compared to OPC [21, 29-31]. In general, raising the content of calcium sulphate results in lower strength of the concrete, while its presence speeds up the hydration process of CSA cement. A lower amount of Ettringite is formed during early hydration when anhydrite is consumed instead of gypsum. This may have resulted in poor early strength development [38-42] for CSA mortar sample. Using fresh portable water, cement is mixed and casted, completely free from the concentration of acids and organic matter.

\section{X-ray diffraction (XRD) for dry cement samples}

XRD study was conducted on the unhydrated powdered cement sample (both for OPC and CSA mixes) to understand the composition of the cement sample and to analyze the minor phases present in the OPC and CSA mixes. X-ray diffraction patterns were measured using an X-ray diffractometer in a $2 \theta$ range of $0-80$. Figure 2(a) shows XRD results for OPC cement. From Fig. 2(a), it can be seen that the OPC cement is largely dominated by elite, calcium hydroxide, and $\mathrm{CaCO}_{3}$, and also sufficient amount of gypsum and belite also formed, contributing to the ultimate strength of the cement. From Fig. 2(b), the composition of CSA-1 can be seen through different diffracted angle. The composition of CSA-1 cement is largely dominated by Ye'elimite and alite. For calcium sulfoaluminate (CSA) cement, Ye'elimite is the main component providing strength to the cement. Apart from Ye'elimite and alite, belite, gypsum, and $\mathrm{CaO}$ are present in lower proportion in CSA Mix-1. The XRD results for CSA-II cement has presented in Fig. 2(c). In CSA-2, the unhydrated cement composition is highly dominated by $\mathrm{CaCO}_{3}, \mathrm{CH}$, Ye'elimite, and alite. Other components such as belite, gypsum, $\mathrm{CaO}$ are also present in CSA-2 cement, serving their intended purpose.

\section{Microstructural study}

\section{Sample preparation}

To study the hydration kinetics, mortar samples were prepared, casted and cured for 28 days for both OPC and CSA binder. Furthermore, the samples are pre-processed for microstructural studies. The water cement ratio (0.4) kept constant for both OPC and CSA mixture to prepare the mortar mix. The cement to sand ratio and other mixing procedure is confirmed to ASTM and IS standards [21, 29-31]. The cement/CSA binder was mixed properly with water to get the uniform paste for about $2 \mathrm{~min}$, and then the 
Fig. 2 X-ray diffractometric analysis of unhydrated cementitious materials (a) OPC cement (b) CSA cement-1 (c) CSA cement-2. G-Gypsum, B-Belite, Y - Ye'elimite (Ca4(AlO2)6SO3), C-C3A, $\mathrm{CH}-$ Calcium Hydroxide, AAlite, $\mathrm{CF}-$ Calcium Ferrite
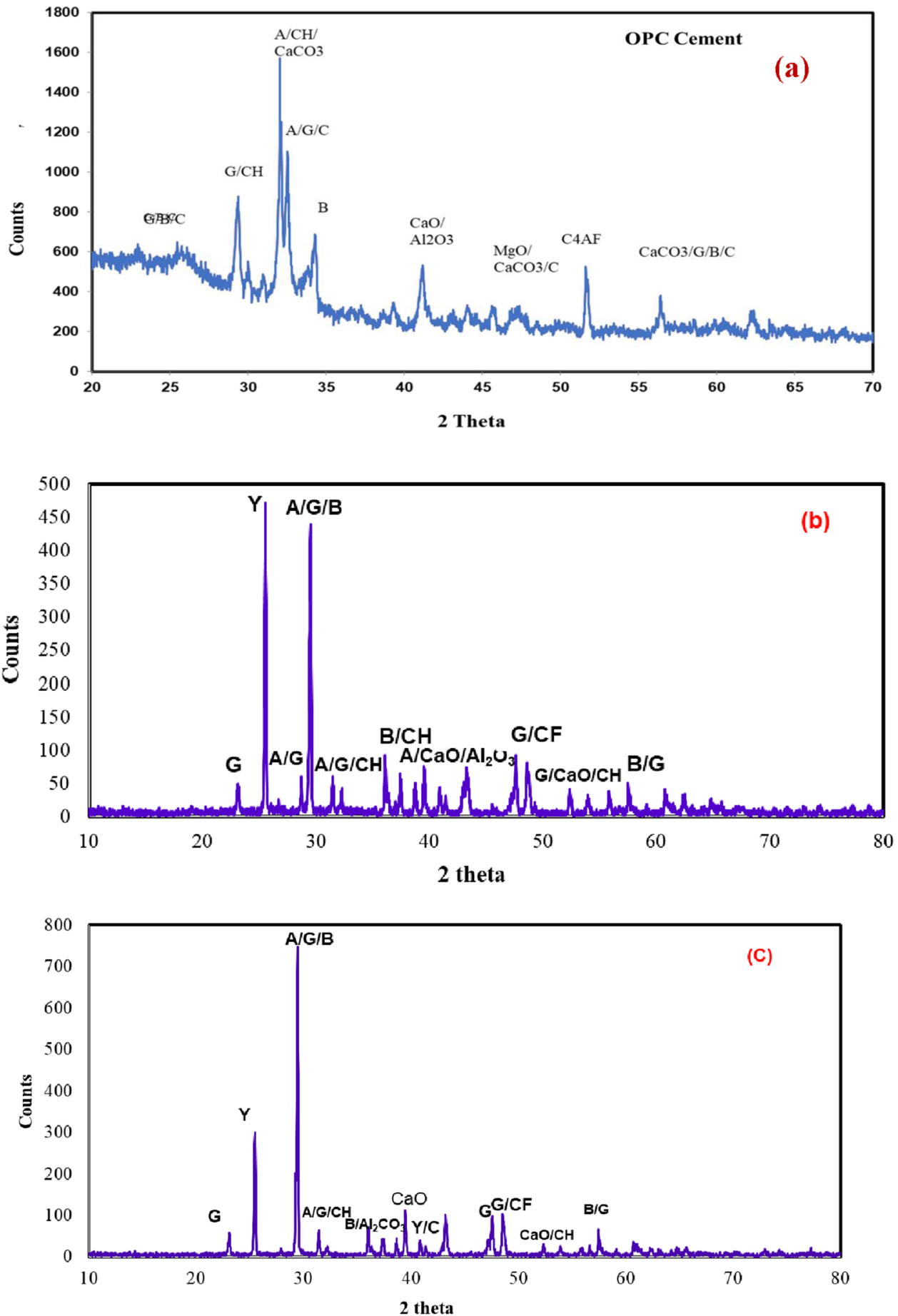

mortar sample were cast in designated mould size and few other in plastic container [29]. The container was sealed and kept at $20{ }^{\circ} \mathrm{C}$. To stop the hydration, a part of the hydrated sample was chipped off from the sample and crushed into powdered form. For CSA cement, the sample is immersed in isopropanol for $15 \mathrm{~min}$ and then washed with diethyl ether. After washing the sample, the sample was dried in the oven at $50{ }^{\circ} \mathrm{C}$ for $10-15 \mathrm{~min}$. OPC cement was washed with acetone and then dried in oven at $50{ }^{\circ} \mathrm{C}$ for $10-15 \mathrm{~min}$.
After taking the sample out from the oven, it was grounded into powder form and then sent for further micro-structural study. The above procedure repeated for preparation powdered sample from 1, 7 and 28 days hydrated cements. To understand the hydration mechanism and products formed during hydration, and pore structure in the hydrated cement sample (both OPC and CSA), tests such as scanning electron microscopy (SEM), thermogravimetric analysis (TGA), and nuclear magnetic resonance (NMR) were performed at 1,7 , 
and 28 days for better evaluation of hydrated CSA and OPC cement samples.

\section{Result interpretation from microstructural study}

\section{SEM results}

SEM enabled microstructural investigation is crucial technique to study the hydration products and it's surface morphology through scanning its surface by a focused beam of electrons. The OPC and CSA mixes were examined by scanning electron microscopy (Nova Nano FE-SEM 450 (FEI)) using backscattered electron microscopy and energy dispersive X-ray (EDS) analysis of polished surfaces. Figure 3 represents the surface morphology and microstructure of OPC cement compounds formed 1, 7 and 28 days of hydration. From Fig. 3(a, b, c), it can be observed that, the most common hydrated compound of OPC i.e., Calcium hydroxide (large surface of crystal-like shape) is formed, which surrounds the CSH interlayer sheet [9-12, 43]. Along with the CSH fibrous sheets, the needle-like structure is well visible, known as Ettringite. The visible black portion can be characterized as the porosity (see Fig. 3(a)). As the hydration proceeds, the microstructure of the cement becomes denser. More of ettringite needles can be seen in Fig. 3(b), and hexagonal plate like structures are also noticeable in SEM image of 7 days hydrated sample, indicates the presence of monosulpho aluminate. As the hydration proceeds further, the OPC structure becomes denser, and porosity decreases to a great extent. From Fig. 3c, it is visible the OPC has achieved sufficient dense structure along with CSH sheet.

The SEM images obtained for CSA-1 shows that the microstructure of the calcium sulfoaluminate cement formed is denser than the OPC cement from the very first day of hydration (see Fig. 4a). At the first day hydration, Calcium hydroxide plates are visible along with crystallized Ettringite. The microstructural images were obtained by SEM, represents the sufficient and homogenous formation of more crystallized needle (Ettringite) like structure embedded within pores (see Fig. 4(a)). As the days proceed, monosulfoaluminate starts forming along with the ettringite needles. The denser structure can be seen at the 7 days of hydration,
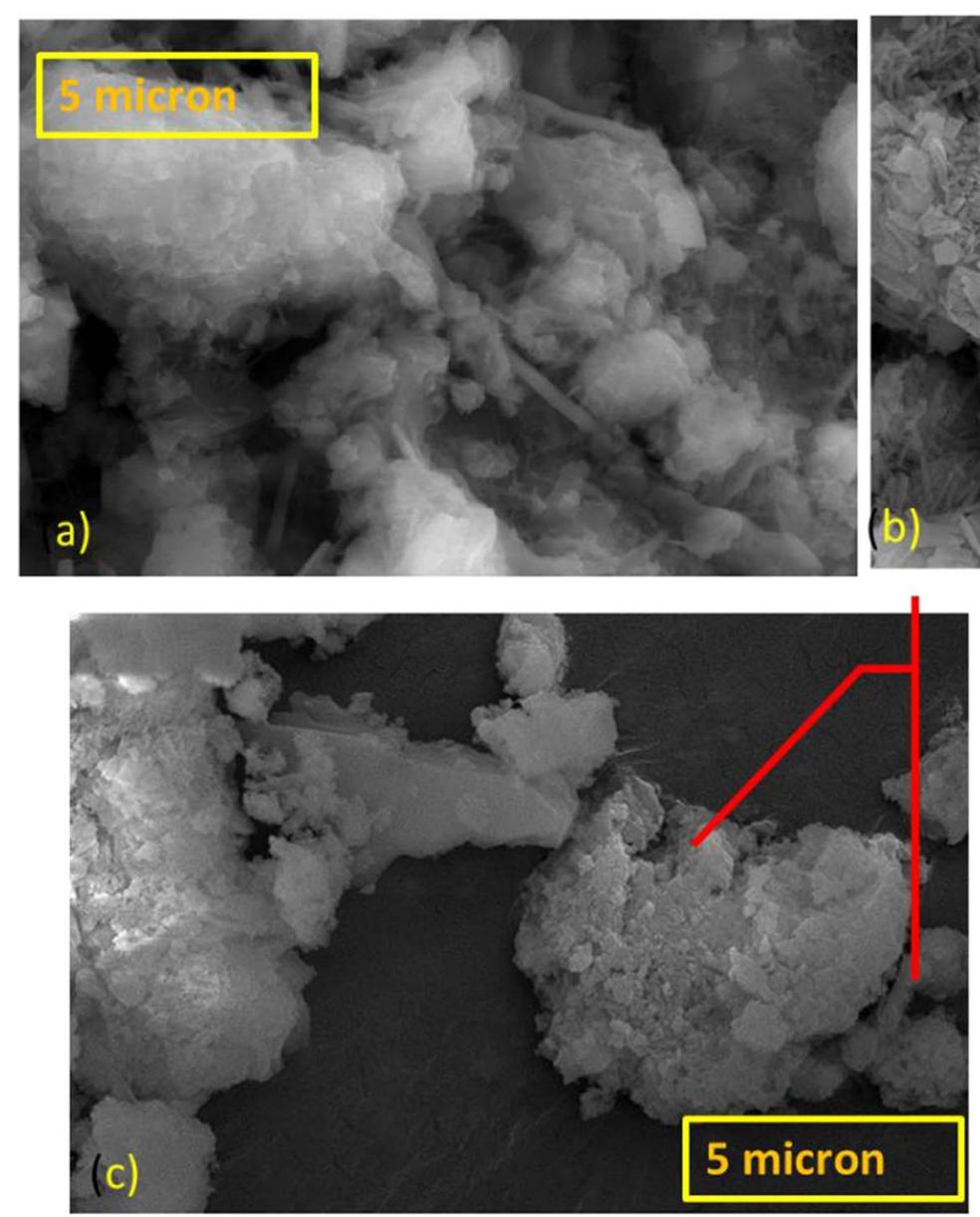
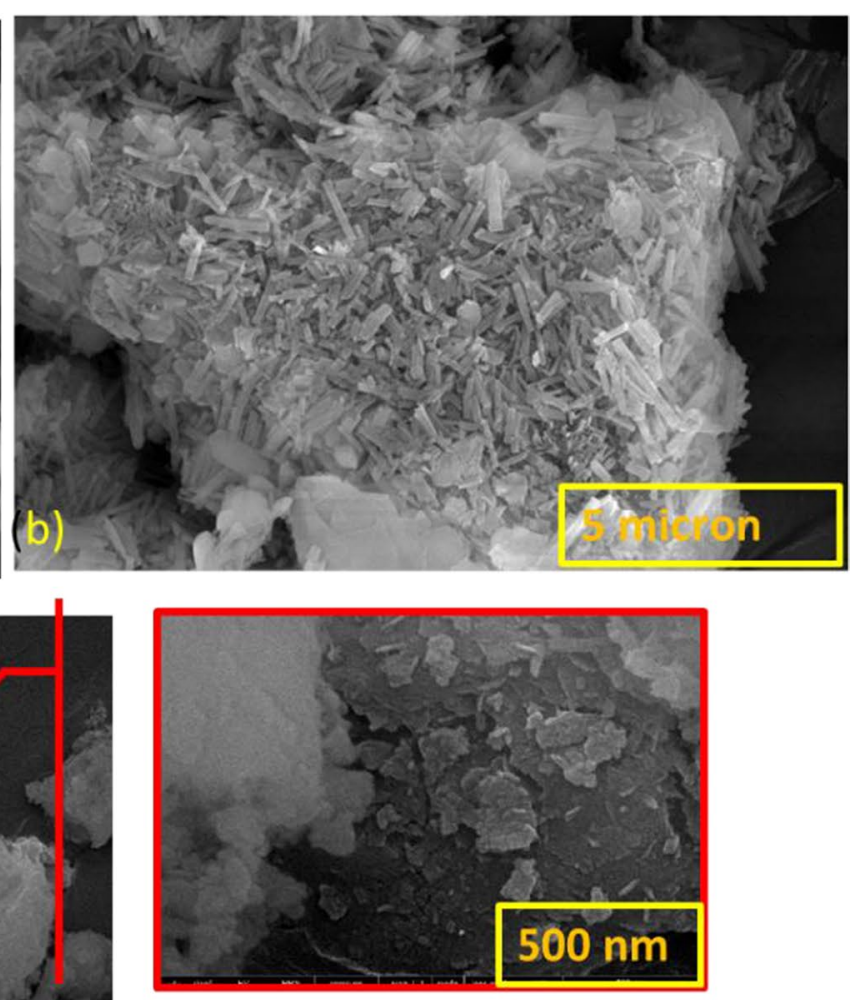

Fig. 3 SEM images of hydrated OPC cement samples (a) 1 day of hydration (b) 7 days hydration (c) 28 days of hydration 

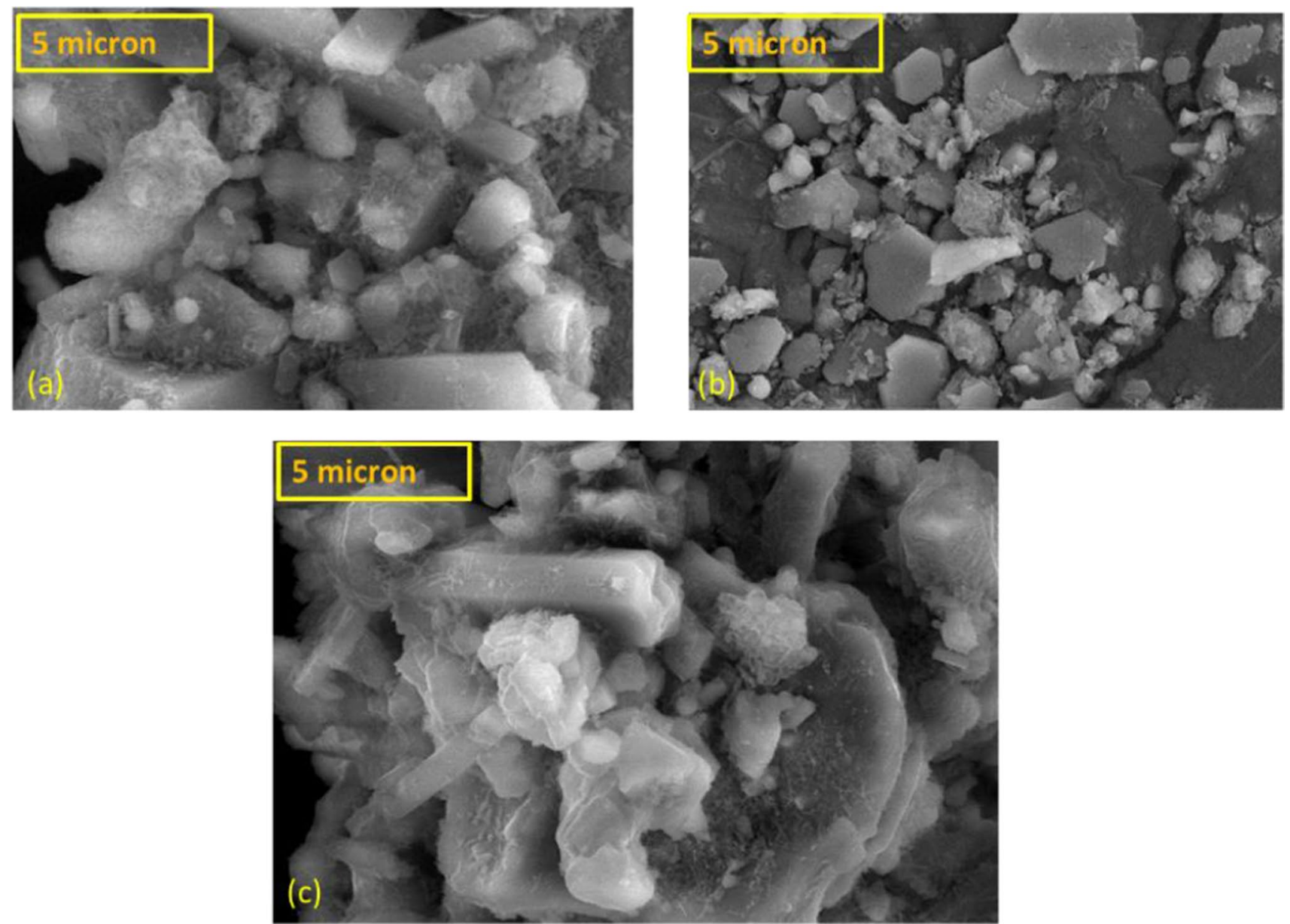

Fig. 4 SEM images of hydrated CSA mix-1 cement samples (a) 1 day of hydration (b) 7 days hydration (c) 28 days of hydration

from Fig. 4(b). As the hydration process complete at 28 days of curing, the structure of the cement composite becomes hardened, hence the SEM images are more dominated hexagonal shaped monosulpho-aluminate and portlandite (Refer Fig. 4(c)).

Figure 5 represents the hydrated cement compounds formed during hydration of CSA mix-2. Figure 5(a) shows the hydration products that were formed till day 1 of hydration. The SEM image implies more ettringite formation with a greater number of pores. Calcium hydroxide along with $\mathrm{CSH}$ fibrous can be seen at the end of 1 day. As the days proceed, ettringite formation increases. At the end of 7 days, a lot more ettringite needles are visible, along with very few monosulfoaluminate i.e. plate like structure formation. At the end of 7 days, porosity also has reduced considerably (see Fig. 5(b)). After completion of 28 days of hydration, a compact and dense structure can be seen with large no of monosulfoaluminate formation. Small amount of ettringite needles are also visible even after the completion of 28 days of hydration, but the hydrated structure seems denser among all the three cement with a lot of monosulfoaluminate and
$\mathrm{CSH}$ formation. At some places, CSH fibers are also visible with sufficient amounts (see Fig. 5(c)). In an overall, the SEM images clearly illustrate the formation of complete hydration and formation of very condensed mortar structure and with uniformly dispersed $\mathrm{CH}$ clusters throughout the surface of hydrated CSA cement products.

\section{TGA results}

For TGA, the sample was crushed into particles having a size of $0.063 \mathrm{~mm}$. The sample was investigated at $20{ }^{\circ} \mathrm{C} /$ min up to $980{ }^{\circ} \mathrm{C}$ for 1,7 , and 28 days, and then a graph is obtained correlating the change in mass with respect to time at a constant temperature rate. Figure 6(a) shows the curves for OPC. For OPC, the TGA plot shows that as the day 1 of hydration completes, the formation of a small amount of Ettringite (weight loss at $50{ }^{\circ} \mathrm{C}-120^{\circ} \mathrm{C}$ ) and $\mathrm{CSH}$ (weight loss at $150{ }^{\circ} \mathrm{C}$ ), clearly depicted through Fig. 6 . The $\mathrm{CH}$ formation is quite evident (weight loss at $400{ }^{\circ} \mathrm{C}$ ), whereas mass loss due to $\mathrm{CaCO}_{3}$ decomposition to $\mathrm{CaO}$ also be seen (weight loss at $800^{\circ} \mathrm{C}$ ) in TGA curve for day 1 of hydration 

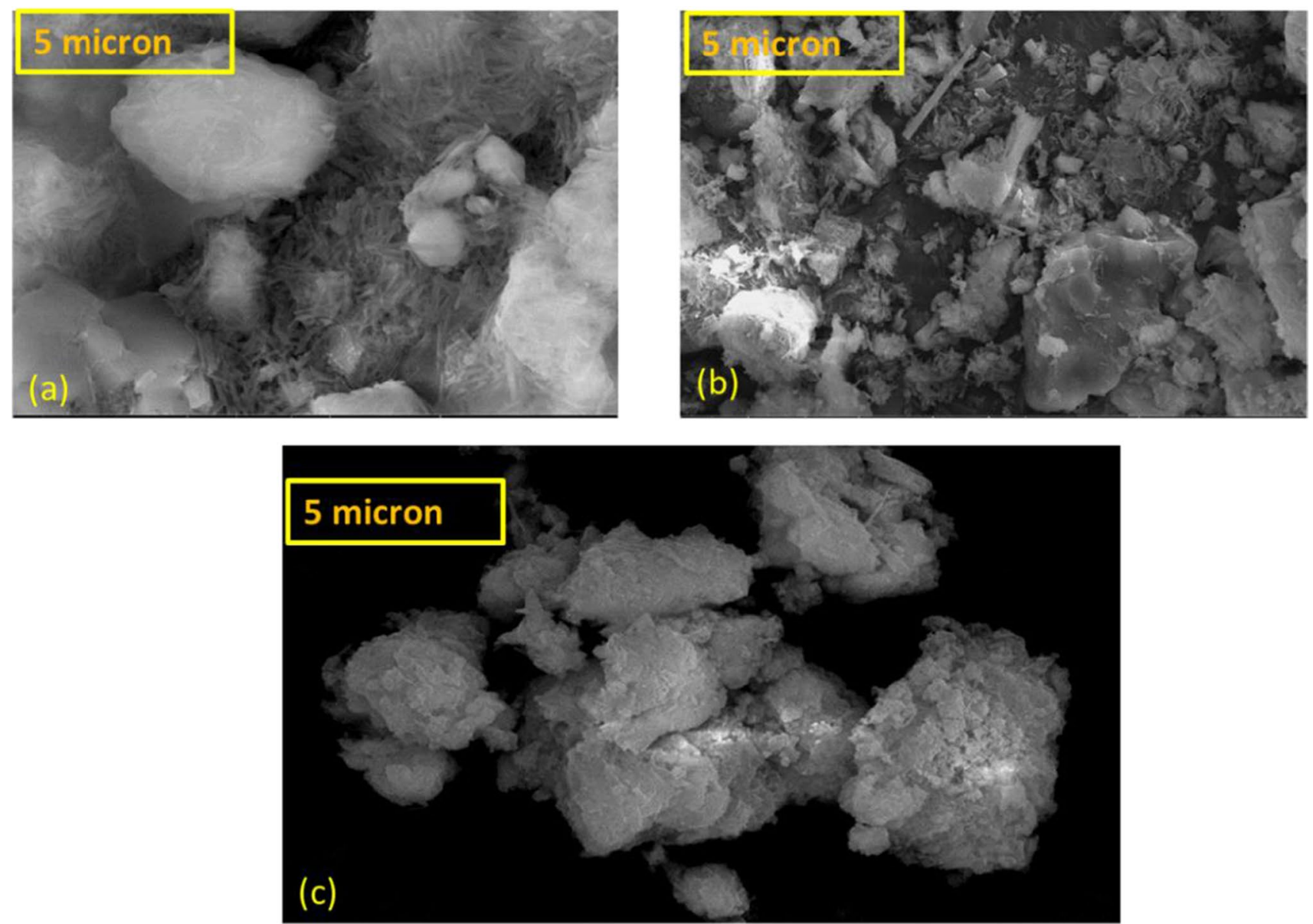

Fig. 5 SEM images of hydrated CSA Mix-2 cement samples (a) 1 day of hydration (b) 7 days hydration (c) 28 days of hydration

of OPC. As the days progresses and percentage of hydrated compound increases, the TGA curve for 7 days of hydration, shows a sharp increase of ettringite quantity (weight loss at $100{ }^{\circ} \mathrm{C}$ ) and an increase in formation $\mathrm{CH}$. Few Monosulfate sheets can also be seen start forming during this time. For 28 days hydration of OPC, The TGA curve represents portlandite formation (weight loss at $400{ }^{\circ} \mathrm{C}$ ). Also, it is seen thatt the ettringite formation slows down, and monosulfate formation increases of TGA curve for 28 days OPC hydration.

Figure 6(b) represents the TGA results for CSA-1. From TGA, it signifies that as the temperature increases from 20 ${ }^{\circ} \mathrm{C}$ to $300{ }^{\circ} \mathrm{C}$, evaporable water is released, different calcium aluminate hydrate phases become dehydrated. The formation Ettringite (AFt), monocarboaluminate \& hemicarboaluminate, and monosulfate caused dehydration at approximately $100{ }^{\circ} \mathrm{C}, 170{ }^{\circ} \mathrm{C}$, and $190{ }^{\circ} \mathrm{C}$, clearly visible in difference in weight curve (refer Fig. 6(b)). The weight loss at approximately $350{ }^{\circ} \mathrm{C}$ has attributed to the small amount of a hydrogrossular, but not clearly interpreted in TGA curve. The dehydration of portlandite $(\mathrm{CH})$ occurs between 400 and $500{ }^{\circ} \mathrm{C}$, clearly interpreted through difference in weight curve. As $\mathrm{CH}$ consumed by the calcined cement, the weight loss between 600 and $800{ }^{\circ} \mathrm{C}$ (i.e. large variation in peak of TGA curve) indicates the decomposition of calcite and release of carbon dioxide to form calcium oxide. The weight loss in this temperature range is related to the amount of limestone added.

For CSA-2 mix, TGA results (see Fig. 6(c)) interprets that the formation of Ettringite (weight loss at $100{ }^{\circ} \mathrm{C}$ ) along with loss due to $\mathrm{CaCO} 3$ decomposition (weight loss at $800{ }^{\circ} \mathrm{C}$ ) is clearly shown for day- 1 of hydration, whereas, for 7 days of hydration reveals more amount of ettringite formation along with monosulfoaluminate and $\mathrm{Al}(\mathrm{OH}) 3$. After completion of 28 days of hydration, the TGA curve shows similar variation as CSA- 1 mix but the difference that large variation of peak occurred between $600{ }^{\circ} \mathrm{C}$ and $800{ }^{\circ} \mathrm{C}$ indicates the higher decomposition rate of calcite and release of carbon dioxide to form calcium oxide [11, 12, 43]. The near flat curves of the calcined cement gave an indication that the kaolinites in the clays have been transformed into metakaolin during the process of calcination. 
(a)

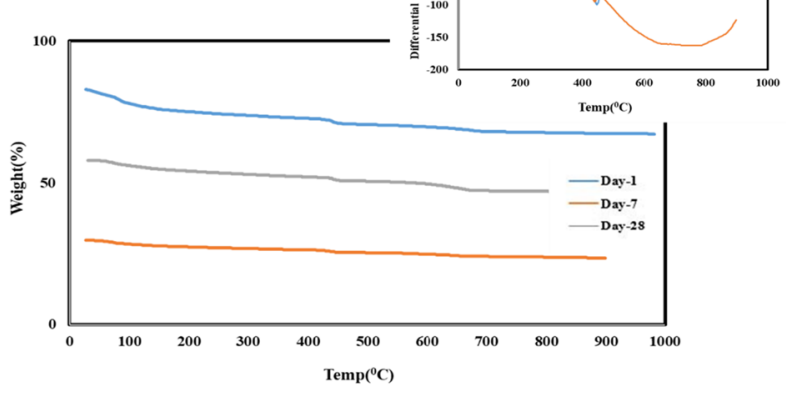

(b)

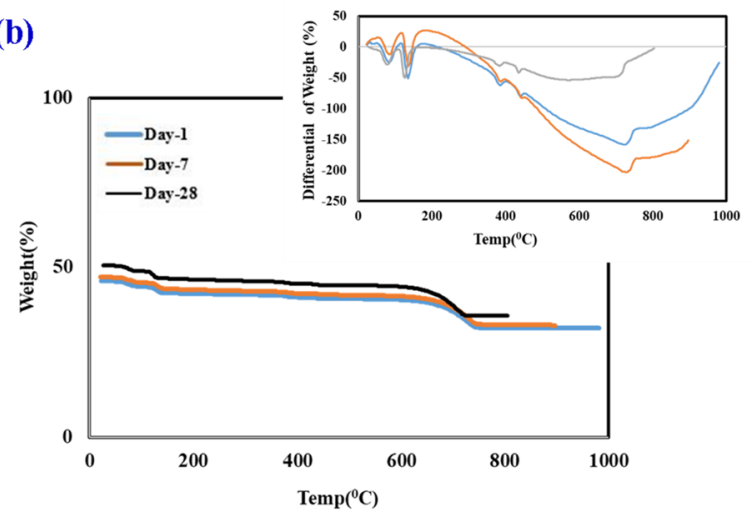

(c)

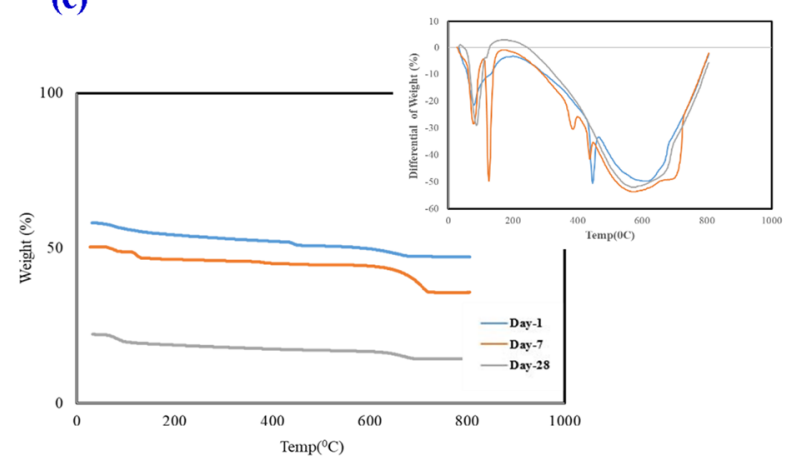

Fig. 6 Thermogravimetric mass loss during hydration for cement samples (a) OPC cement (b) CSA -1 (c) CSA-2

\section{NMR results}

Figures 7, 8, and 9 provides $1 \mathrm{H}$ NMR spectra of OPC, CSA-1, and CSA-2 cement. The samples were examined by Nuclear Magnetic Resonance (solid-state NMR) (ECS $400 \mathrm{MHz}$ (JEOL) NMR spectrometer). All three cement samples were cured and hydrated for 28 days to get a brief idea about hydration products forming during the curing process. The spectra yield signal in the range of 1-5 ppm. The H NMR graphs produce a range of peaks of the hydration product, have occurred during curation for 28 days. Figure 7 presents a brief idea about the NMR spectra of the Ordinary Portland Cement at 1, 7, and 28 days. For day-1, three peaks occur in the range of $0.5-1.5$, which tells about the hydrogen atom substitution for Aluminium and sulfur substitution in Ettringite. Peaks lie between 2.0 - 3.0 are mainly showing hydrogen substitution for $\mathrm{Ca}$ in $\mathrm{CSH}$ and Calcium hydroxide. As the hydration progress, an increase in ettringite formation can be seen with monosulfate formation in the range of $0.5-5$ for day 7 hydration of OPC. All the other peaks are visible for day 7 cured hydrated cement compound in their respective ranges, same as seen of NMR peaks day -1 hydration. As the hydration period increase, a substantial growth in CSH Fiber (around a peak of 2.2 to 2.5) also seen NMR results for 28 days of curing. There is a decrease in unhydrated paste for 28 days cured OPC cement, visible in the peak range of 3.22 to 3.25 of NMR results. The different phases of Ettringite and monosulfate are difficult to detect in Proton NMR; hence only a specific range can be defined.

Figure 8 shows NMR spectra for CSA-1 mix. For CSA-1 cement, the ranges of the peak are slightly different from the ordinary Portland cement. At 1, 7, and 28 days, three peaks occur in the range of $0.5-1.5$, which tells about the hydrogen atom substitution for Aluminum and sulfur substitution in Ettringite and monosulfate. Peaks in between $2.0-3.0$ mainly show hydrogen substitution for $\mathrm{Ca}$ in $\mathrm{CSH}$, whereas the peak which occurs in the range 3.0-3.5 is hydrogen substitution for $\mathrm{Ca}$ available in calcium hydroxide and the unhydrated cement paste. For Calcium sulphoaluminate (CSA) mixes, one major change in peak is noticed in the range 4.0-4.5 is represents the strangilite (see both Figs. 9(b) and $8(b))$. Occurrence of other compounds are similar as that of CSA-1 mix (see Fig. 9(a)). It is quite pertinent from Fig. 9 that the large presence of Ettringite and strangilite increases as the hydration process increases for calcined clay cement, signifies decrease in. decrease in CSH fibrous content (see Fig. 9(a) and (b)).

\section{Ternary diagram}

To understand the occurrence of different cement phase compounds occurred in normal OPC and CSA mixes, the plot ternary phase diagram is a very effective tool. This can be done with basic thermodynamic calculation using the mass balance concept of different cement hydrated phases [39]. For different calculation compositions of clinker and it is cementing behaviour, the author used excel templet Proposed by Prof. Barbara Lothenbach, which includes geochemical data of typical compositions for Portland cement, limestone, fly ash, silica fume, and clay used [44]. To use this templet the author obtained the chemical compositional analysis of OPC cement and CSA mixes i.e. CSA-1 and CSA-2 through ideal ionization source for mass spectrometry (ICP-MS). Having the chemical composition of CSA clinkers and OPC, the user is free to enter any composition of interest within the 8-component system [9, 10, 40, 45]. 


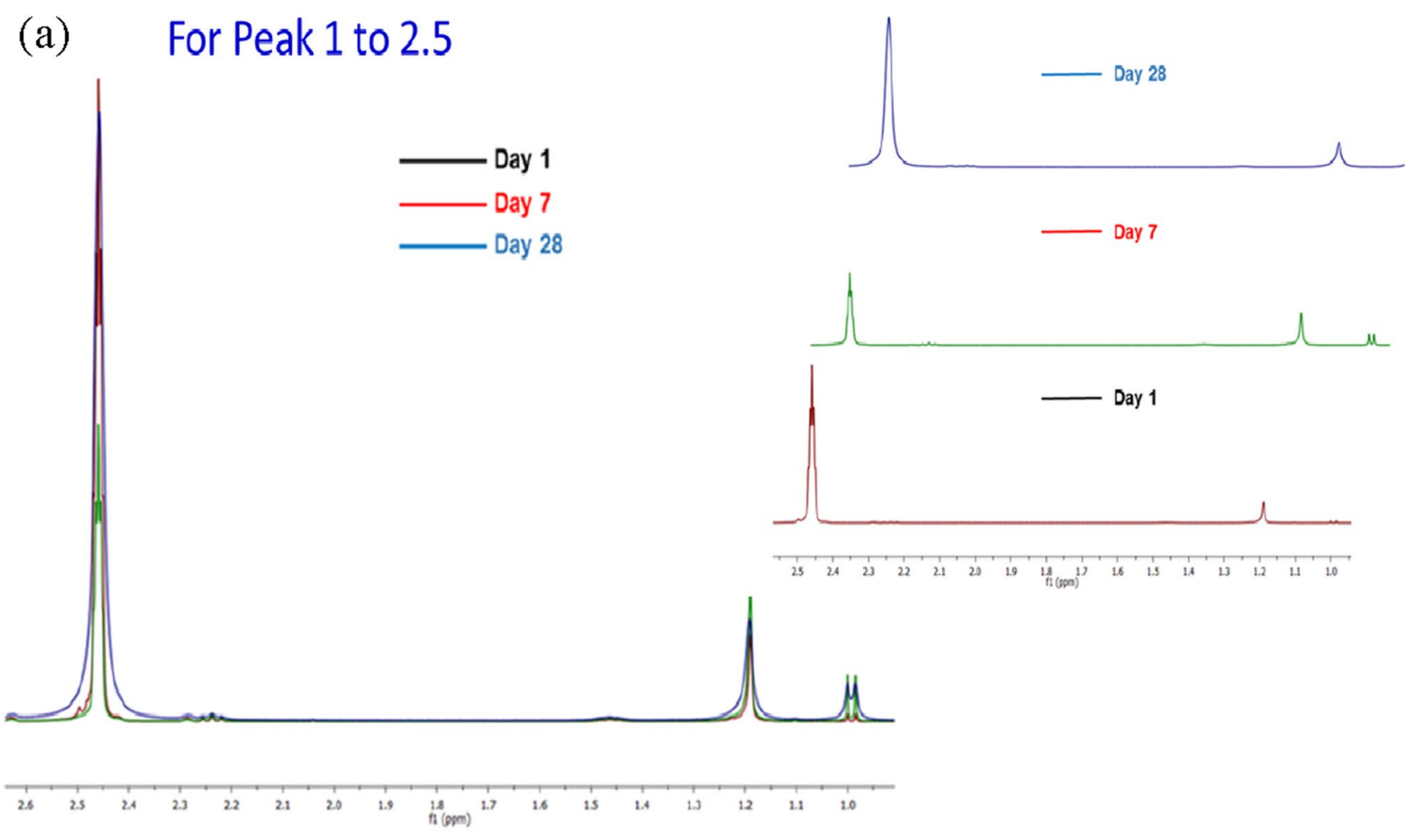

(b)

For Peak 3 to 3.5

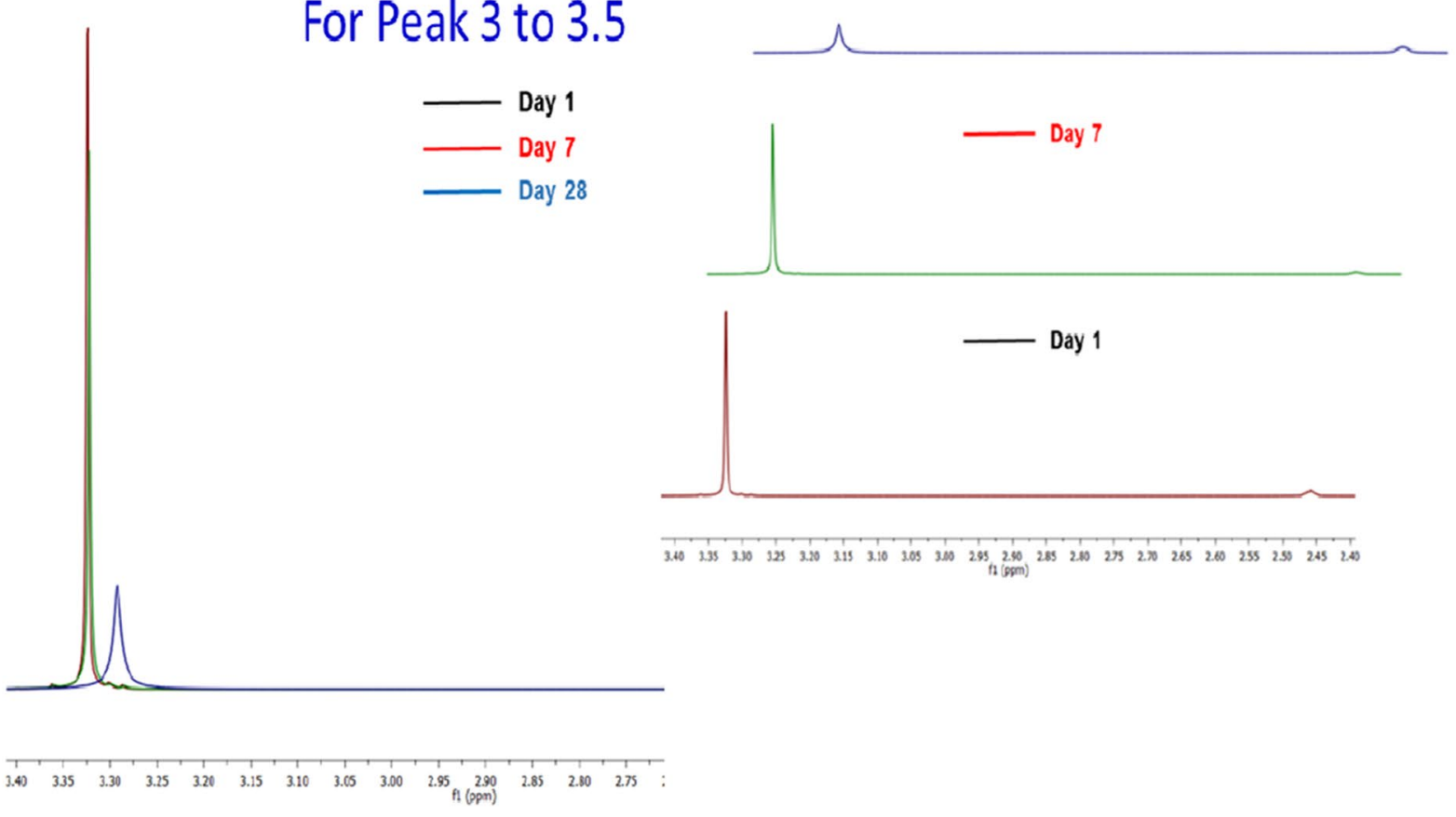

Fig. 7 NMR results for OPC cement for 1,7, 28 days of hydration (a) For Peak range 1-2.5 (b) for peak range 3 to 3.5 
(a)

For Peak 1 to 2.5

Day 1

Day 7

Day 28
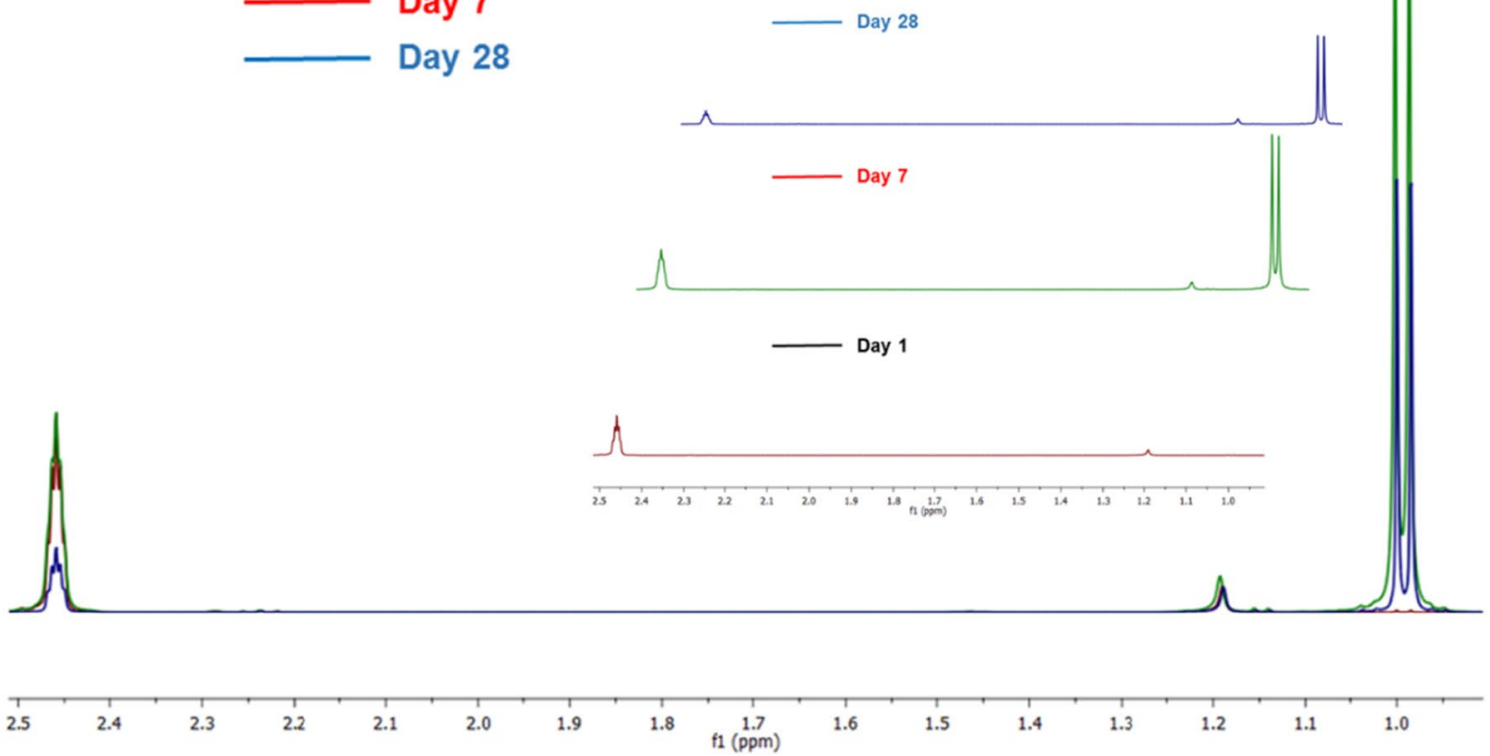

(b)

For peak 2.5 to 4.5

Day 1

Day 7

Day 28
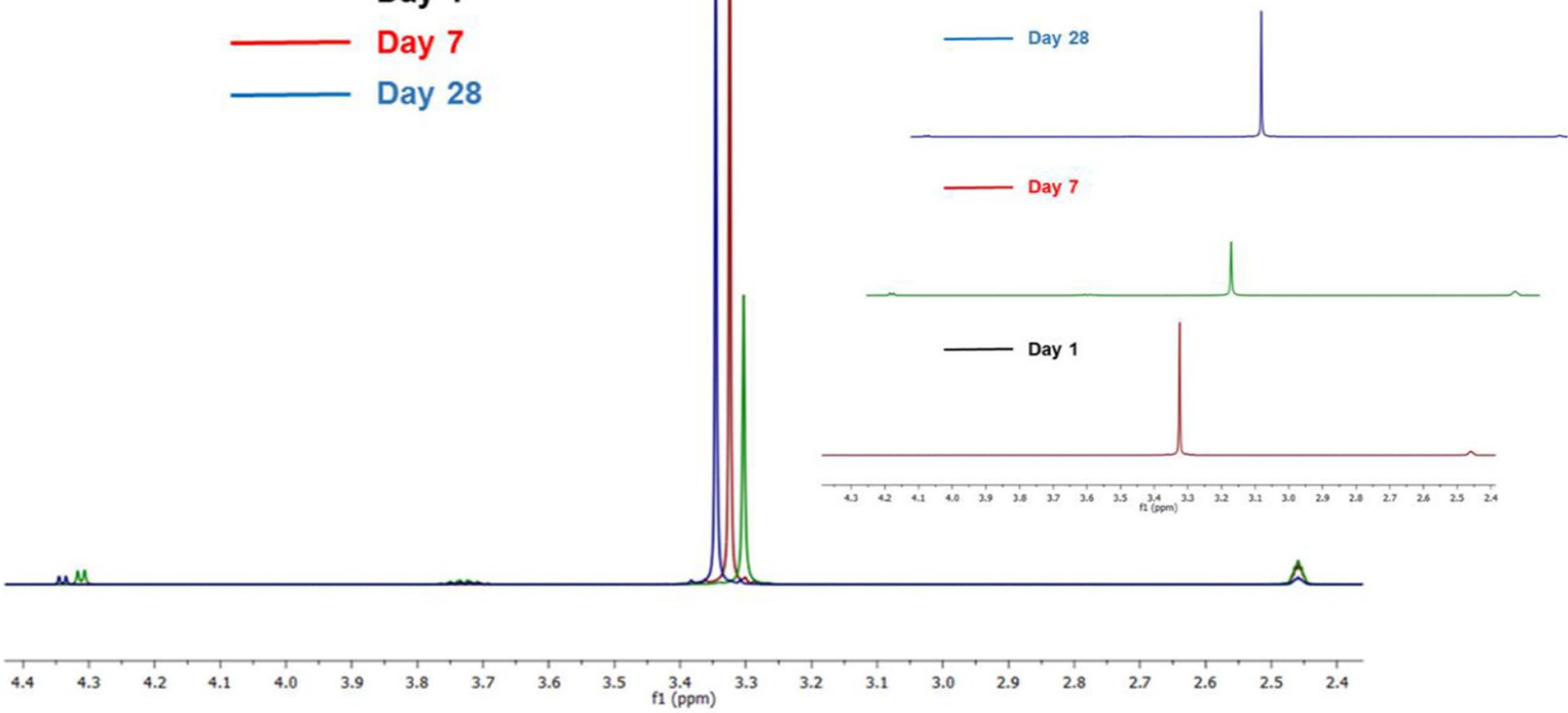

Fig. 8 NMR results for CSA mix-1 cement for 1, 7, 28 days of hydration (a) For Peak range 1-2.5 (b) for peak range 2.5 to 4.5

Figure $10(a, b$, and $c)$ shows the ternary diagram obtained for the entire three-cement sample. The boundaries shown in Fig. 10 are only an approximation of the limits of the possible solid solutions. From Fig. 10(a), it is clearly visible that ordinary Portland cement lies in between $\mathrm{CaO}$ and $\mathrm{SiO} 2$. Qualitatively it can be seen that it has more amount 
(a)

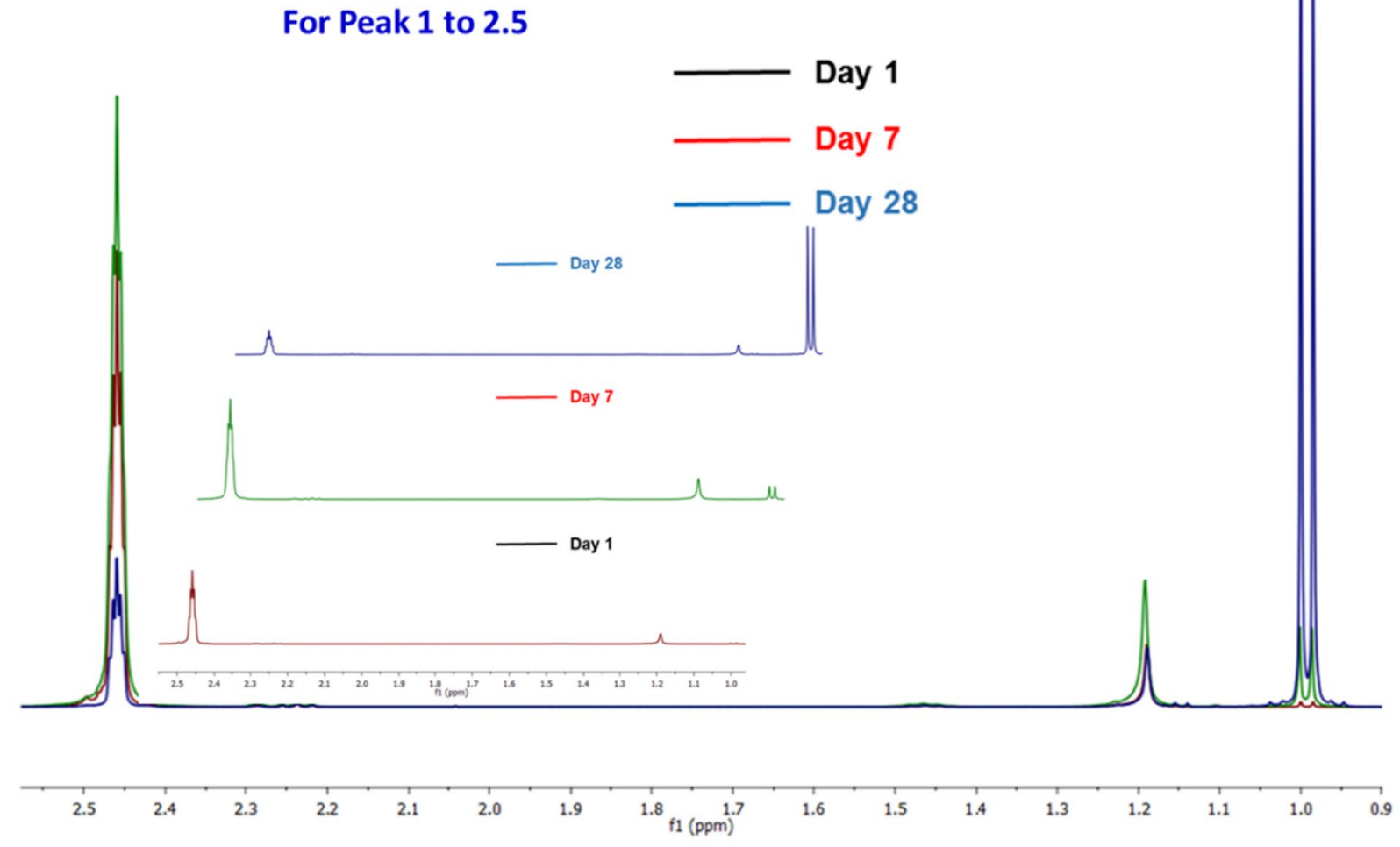

(b)

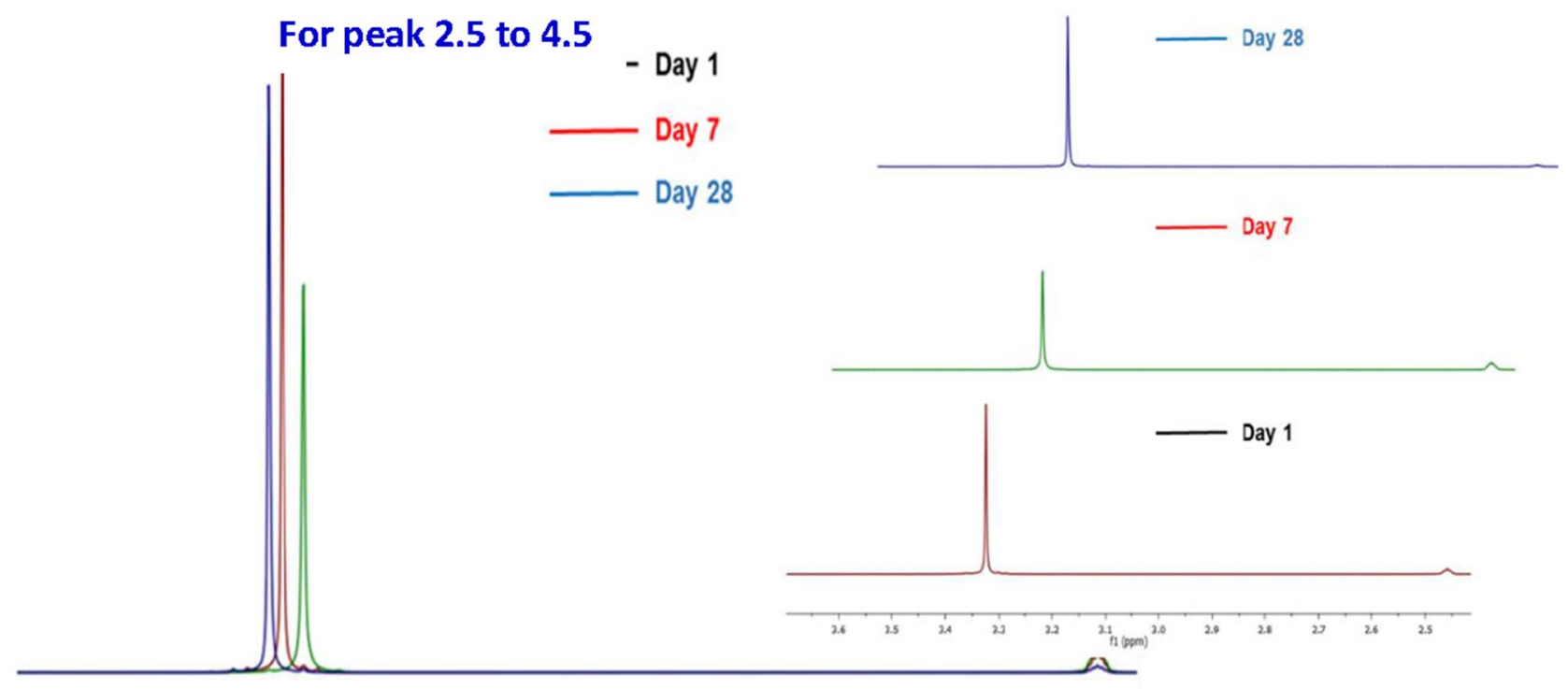

$\begin{array}{llllllllllllllllllllllllllllllllllll}3.60 & 3.55 & 3.50 & 3.45 & 3.40 & 3.35 & 3.30 & 3.25 & 3.20 & 3.15 & 3.10 & 3.05 & 3.00 & 2.95 & 2.90 & 2.85 & 2.30 & 2.75 & 2.70 & 2.65 & 2.60 & 2.55 & 2.50 & 2.45\end{array}$

Fig. 9 NMR results for CSA Mix-2 cement sample for 1, 7, 28 days of hydration (a) For Peak range 1-2.5 (b) for peak range 2.5 to 4.5 


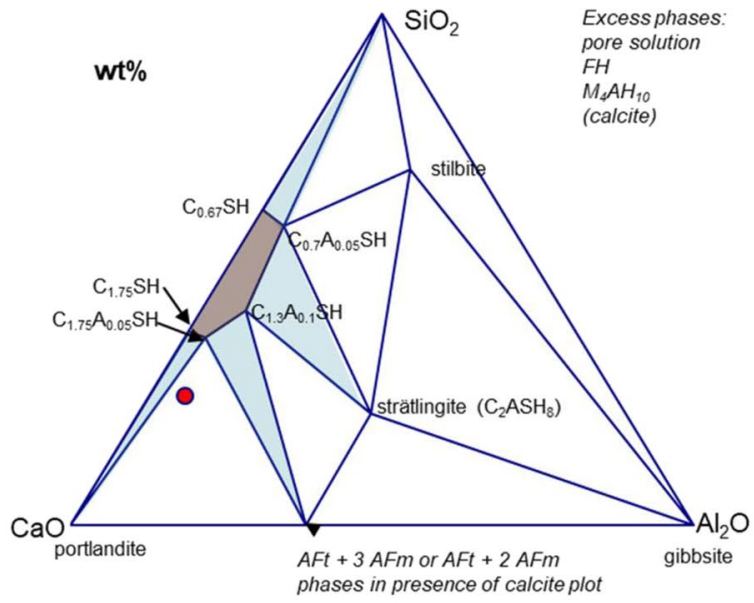

(a)

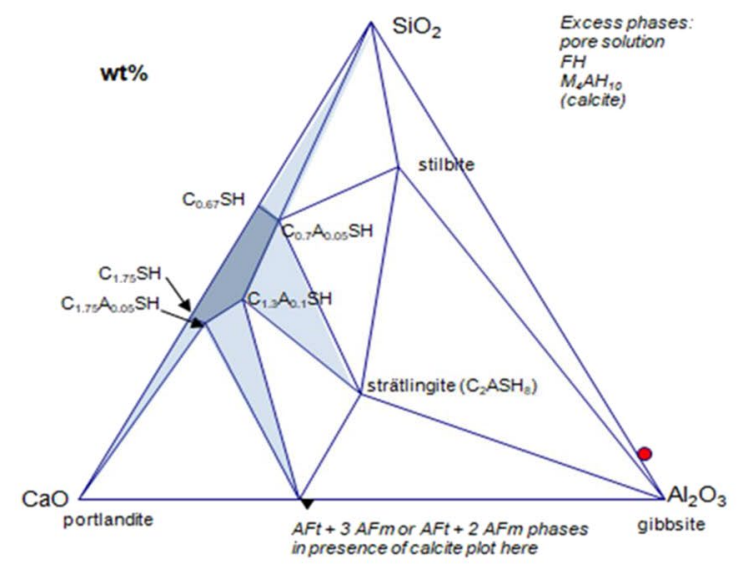

(b)

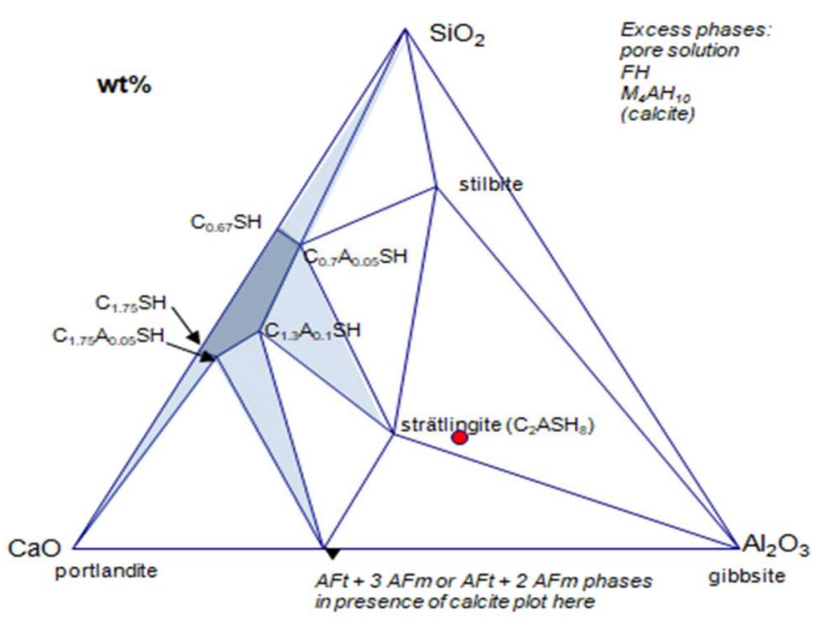

(c)

Fig. $10 \mathrm{CaO}-\mathrm{A} 12 \mathrm{O} 3-\mathrm{SiO} 2$ ternary diagram of cementitious materials (a) OPC Cement (b) CSA Mix-1 cement (c) CSA mix-2 Cement of portlandite and the formation of more $\mathrm{C}-\mathrm{S}-\mathrm{H}$ with a higher $\mathrm{C} / \mathrm{S}$ ratio. In the ternary diagram of CSA-1 cement, the barycentre is more oriented towards the aluminium side, which means that more aluminous compared to others (see Fig. 10(b)). Figure 10(c) represents the ternary diagram of CSA-2 cement. From Fig. 10(c), it can be seen that the cement lies in between the aluminium oxide and calcium oxide, which indicates both the calcareous and aluminous nature of CSA-2. From ternary structure of CSA-2, it is found that the clinkering calcined clay cement more successful in terms of both strength and setting properties.

\section{Conclusions}

This paper comprises the clinkering of calcium sulfoaluminate cement using local industrial.

waste and its microstructural characterization to understand their cementing behaviour. The two CSA mixes have prepared by varying basic raw materials needed for any Portland cement with addition marble slurry and metakaolin. The basic physical properties of both CSA cement along OPC have been studied in laboratory tests. From laboratory tests, it is found that the CSA cements have a lower setting time period as compared to OPC but higher specific gravity, specific surface area than the ordinary Portland cement. The microstructural studies were done for both hydrated cement (SEM, TGA, and NMR) and unhydrated cement (XRD). The composition of the ordinary Portland cement is dominated mainly by elite, belite with a lesser amount of Calcium aluminates and calcium aluminoferrites, whereas in both the CSA cement samples, Ye'elimite dominates the composition with belite and alite along with ferrites, magnesium hydroxides, which are produced in a lesser amount. From SEM results, it is found that for CSA cements, CSH fiber along with calcium hydroxide starts forming as soon as the hydration process starts. Ettringite and monosulfoaluminate keeps on forming till the hydration process stops, whereas in ordinary Portland cement, portlandite, is also formed as a major hydration product along with the Ettringite and monosulfoaluminate. The SEM results can also be confirmed by TGA (mass changes/weight loss during the formation of hydrated product) and NMR results (present of hydrated product/ compounds for given mixture). Finally, ternary diagrams were plotted to identify the cementitious behaviour for both OPC and CSA mixes by visualizing the ratios between the three variables $(\mathrm{Ca}, \mathrm{Si}$, and $\mathrm{Al})$. The barycentre (red dot) for CSA-2 is found to be balanced between calcite and alumnus properties. Overall, the complete microstructural study of CSA mixes have done, and from the proposed study, it can be concluded that CSA cement has a large potential for floor screeding and repair and retrofitting purpose because of its good cementing nature. 


\section{Declarations}

Conflict of interest On behalf of all authors, the corresponding author states that there is no conflict of interest.

\section{References}

1. Andrew RM (2018) Global CO2 emissions from cement production. Earth Syst Sci Data 10(1):195-217. https://doi.org/10.5194/ essd-10-195-2018

2. Bentz DP (1997) Three-dimensional computer simulation of portland cement hydration and microstructure development. J Am Ceram Soc 80(1):3-21. https://doi.org/10.1111/j.1151-2916. 1997.tb02785.x

3. Shi C, Jiménez AF, Palomo A (2011) New cements for the 21st century: The pursuit of an alternative to Portland cement. Cem Concr Res 41(7):750-763. https://doi.org/10.1016/j.cemconres. 2011.03.016

4. Chen IA, Hargis CW, Juenger MCG (2012) Understanding expansion in calcium sulfoaluminate-belite cements. Cem Concr Res 42(1):51-60. https://doi.org/10.1016/j.cemconres.2011.07.010

5. Winnefeld F, Lothenbach B (2010) Hydration of calcium sulfoaluminate cements - Experimental findings and thermodynamic modelling. Cem Concr Res 40(8):1239-1247. https://doi.org/10. 1016/j.cemconres.2009.08.014

6. Lothenbach B, Le Saout G, Gallucci E, Scrivener K (2008) Influence of limestone on the hydration of Portland cements. Cem Concr Res 38(6):848-860. https://doi.org/10.1016/j.cemconres. 2008.01.002

7. Zajac M, Rossberg A, Le Saout G, Lothenbach B (2014) Influence of limestone and anhydrite on the hydration of Portland cements. Cem Concr Res 46:99-108. https://doi.org/10.1016/j. cemconcomp.2013.11.007

8. Marroccoli M, Pace ML, Telesca A, Valenti GL (2010) Synthesis of calcium sulfoaluminate cements from $\mathrm{Al} 2 \mathrm{O} 3$-rich by-products from aluminium manufacture. 2nd International Conference on Sustainable Construction Materials and Technologies

9. Rodriguez C, Tobon JI (2020) Influence of calcined clay/limestone, sulfate and clinker proportions on cement performance. Constr Build Mater 10(251):119050. https://doi.org/10.1016/j. conbuildmat.2020.119050

10. Krishnan S, Bishnoi S (2020) A numerical approach for designing composite cements with calcined clay and limestone. Cem Concr Res 1(138):106232. https://doi.org/10.1016/j.cemconres. 2020. 106232

11. Krishnan S, Gopala Rao D, Bishnoi S (2020) Why Low-Grade Calcined Clays Are the Ideal for the Production of Limestone Calcined Clay Cement (LC 3). In Calcined Clays for Sustainable Concrete 2020 (pp. 125-130). Springer, Singapore

12. Sharma M, Bishnoi S, Martirena F, Scrivener K (2021) Limestone calcined clay cement and concrete: A state-of-the-art review. Cem Concr Res 1(149):106564. https://doi.org/10.1016/j.cemconres. 2021.106564

13. Martin LHJ, Winnefeld F, Müller CJ, Lothenbach B (2015) Contribution of limestone to the hydration of calcium sulfoaluminate cement. Cem Concr Res 62:204-211. https://doi.org/10.1016/j. cemconcomp.2015.07.005

14. Maddalena R, Roberts JJ, Hamilton A (2018) Can Portland cement be replaced by low-carbon alternative materials? A study on the thermal properties and carbon emissions of innovative cements. J Cleaner Prod 186:933-942. https://doi.org/10.1016/j.jclepro.2018. 02.138
15. Winnefeld F, Lothenbach B (2016) Phase equilibria in the system $\mathrm{Ca} 4 \mathrm{Al} 6 \mathrm{O} 12 \mathrm{SO} 4-\mathrm{Ca} 2 \mathrm{SiO} 4-\mathrm{CaSO} 4-\mathrm{H} 2 \mathrm{O}$ referring to the hydration of calcium sulfoaluminate cements. RILEM Tech Lett 1:10-16. https://doi.org/10.1016/j.fluid.2009.12.008

16. Binici H, Shah T, Aksogan O, Kaplan H (2008) Durability of concrete made with granite and marble as recycle aggregates. J Mater Process Technol 208(1-3):299-308. https://doi.org/10. 1016/j.jmatprotec.2007.12.120

17. Chitvoranund N, Winnefeld F, Hargis CW, Sinthupinyo S, Lothenbach B (2017) Synthesis and hydration of alite-calcium sulfoaluminate cement. Adv Cem Res 29(3):101-111. https://doi. org/10.1680/jadcr.16.00071

18. Hargis CW, Lothenbach B, Müller CJ, Winnefeld F (2017) Carbonation of calcium sulfoaluminate mortars. Cem Concr Compos 80:123-134. https://doi.org/10.1016/j.cemconcomp.2017. 03.003

19. ASTM C595/C595M-10 (2010) Standard Specification for Blended Hydraulic Cements, ASTM Vol. 04.01. ASTM International, West Conshohocken, USA

20. IS 1489 (1991) Indian standard Portland-Pozzolana CementSpecification Part2- Calcined clay based

21. IS 12600: 1989 (2009) Portland cement, low heat specification

22. Zhou D, Wang R, Tyrer M, Wong H, Cheeseman C (2017) Sustainable infrastructure development through use of calcined excavated waste clay as a supplementary cementitious material. J Clean Prod 168:1180-1192

23. Assaad JJ, Issa CA (2014) Effect of clinker grinding aids on flow of cement-based materials Cem. oncr. Res 63:1-11. https://doi. org/10.1016/j.cemconres.2014.04.006

24. Katsioti M, Tsakiridis PE, Giannatos P, Tsibouki Z, Marinos J (2009) Characterization of various cement grinding aids and their impact on grindability and cement performance. Constr Build Mater 23:1954-1959. https://doi.org/10.1016/j.conbuildmat.2008. 09.003

25. Sohoni S, Sridhar R, Mandal G (1991) The effect of grinding aids on the fine grinding of limestone, quartz and Portland cement clinker. Powder Technol. 67: 277-286. 10. 1016/0032-5910(91)80109-V

26. IS:10262:2009 Concrete Mix Proportioning - Guidelines, Bureau of Indian Standards, New Delhi

27. IS 383 (1970) Specification for Coarse And Fine Aggregates From Natural Sources For Concrete, Bureau of Indian Standards, New Delhi.

28. Hargis CW, Telesca A, Monteiro PJM (2014) Calcium sulfoaluminate (Ye'elimite) hydration in the presence of gypsum, calcite, and vaterite. Cem Concr Res 65:15-20. https://doi.org/10.1016/j. cemconres.2014.07.004

29. ASTM C114-09 Standard Test Methods for Chemical Analysis of Hydraulic Cement

30. ASTM C150-05 Standard Specification for Portland Cement

31. Is 8112:2013 ordinary portland cement, 43 grade — specification

32. Cuesta A, Álvarez-Pinazo G, Sanfélix SG, Peral I, Aranda MAG, De La Torre AG (2014) Hydration mechanisms of two polymorphs of synthetic ye'elimite. Cem Concr Res 63:127-136. https://doi.org/10.1016/j.cemconres.2014.05.010

33. Jansen D, Spies A, Neubauer J, Ectors D, Goetz-Neunhoeffer F (2017) Studies on the early hydration of two modifications of ye'elimite with gypsum. Cem Concr Res 91:106-116. https://doi. org/10.1016/j.cemconres.2016.11.009

34. Londono-Zuluaga D, Tobón JI, Aranda MAG, Santacruz I, De la Torre AG (2017) Clinkering and hydration of belite-aliteye'elimite cement. Cem Concr Compos 80:333-341. https://doi. org/10.1016/j.cemconcomp.2017.04.002

35. Aranda MAG, De la Torre AG (2013) Sulfoaluminate cement. In Eco-Efficient Concrete. (488-522). Woodhead Publishing. https:// doi.org/10.1533/9780857098993.4.488 
36. Péra J, Ambroise J (2004) New applications of calcium sulfoaluminate cement. Cem Concr Res 34(4):671-676. https://doi.org/ 10.1016/j.cemconres.2003.10.019

37. Yanmou W, Jun'an D, Muzen S (1986) An investigation into cement $\mathrm{CaO}-\mathrm{SiO} 2$-Al2O3 - $\mathrm{Fe} 2 \mathrm{O} 3$-SO3 system. In Proceedings of the 8th International Congress, Rio de Janeiro, Brazil, 22-27 September 1986

38. Sahu S, Havlica J, Tomkova V, Majling J (1991) Hydration behaviour of sulphoaluminate belite cement in the presence of various calcium sulphates. Thermochim Acta. 175(1):45-52. https://doi. org/10.1016/0040-6031(91)80244-D

39. Palou MT, Majling J (1996) Hydration in the system C4A3SCSH2-CH. J. Therm. Anal. Calorim. 46(2):557-563. 46:557-63

40. Pe'ra J, Ambroise J, Holard E, Beauvent G (2003) Influence of the type of calcium sulfate on the properties of calcium sulfoaluminate cement. In: Eleventh international congress on the chemistry of cements, Durban, South Africa, May 11-16, 2003, vol. 3, p. 1129-35
41. Winnefeld F, Barlag S (2010) Calorimetric and thermogravimetric study on the influence of calcium sulfate on the hydration of ye'elimite. J Therm Anal Calorim 101:949-957

42. Scrivener K, Snellings R, Lothenbach B (Eds) (2018) A practical guide to microstructural analysis of cementitious materials. CRC Press

43. Muzenda TR, Hou P, Kawashima S, Sui T, Cheng X (2020) The role of limestone and calcined clay on the rheological properties of LC3. Cem Concr Compos 1(107):103516. https://doi.org/10. 1016/j.cemconcomp.2020.103516

44. Lothenbach B (2018) Calculation of ternary diagrams by mass balance calculations in MS Excel. (n.d.) retrieved in January 14, 2020, from EMPA Switzerland Interactive website: https://www. empa.ch/web/s308/ternary-diagram

45. Lin RS, Han Y, Wang XY (2021) Macro-meso-micro experimental studies of calcined clay limestone cement (LC3) paste subjected to elevated temperature. Cem Concr Compos 1(116):10387. https://doi.org/10.1016/j.cemconcomp.2020.103871 